2005 年, ミネルヴァ書房, ISBN4-623-04080-1，7,875 円

(税込)

\title{
飯 田哲也
}

著者は 1989 年に『中国の人口問題』を，1996 年に『現代中国の人口問題と社会変動』を刊行し ており, 本書はその延長線上に位置づけて比較検 討することが望ましいが, 紙数の関係上そのよう に論じることはできない。『中国の人口問題』はこ のテーマを全体的に論じた試みとして意義があ り,『現代中国の人口問題之社会变動』はこのテー マをめぐるその後の推移を社会的変化と結びつけ てフォローする性格のものであるという確認だけ しておこう。さて本書は,

第 1 章 世界の人口爆発之その構図变動 第 2 章 世界人口爆発と民族問題第 3 章 リプロ ダクティブ・ヘルス/ライッをめぐって 第 4 章 中国における人口・環境・食糧問題 第 5 章 1 人っ子政策の登場と法制化 第 6 章 人口動態 の推移々人口統計 第 7 章 1 人っ子政策の直面 する難題その後 第 8 章 経済開放下の人口・ 労働力移動 第 9 章 巨大都市・上海市にみる 人口第 10 章 国際人口移動をめぐる中国と日 本 第 11 章 環境問題における人口抑制の意味 第 12 章 人口高齢化と老人扶養・社会保障制度 改革 第 13 章 少数民族人口事情

という構成で 500 頁を超える大きな本である。 「やや網羅的記述になった」之著者自身も述べて いる本書全体を要約して紹介することもできな い。膨大な統計資料・文献 (主に日本語だが) そ して現地調査（主として参与観察と聞き取り）と いうエネルギッシュな取り組みにまずは敬意を表 したい。しかしどちらかと言えば，「世界の人口問 題」という性格であり, 『家族社会学研究』よりも 『社会学評論』で取り上げる性格の本であるよう に思われる。以下では, 第 4 章, 第 6 章, 第 7 章, 第 12 章に限定して若干の言及をするにすぎな

いいだてつや：立命館大学
い。統計資料による具体的数字の変化動向にまで 言及するとこれまた膨大であり，しかもその大部 分を省くことができなくなるからである。

第 4 章では, 人口分布の地域的不均衡を軸之し て，いわゆる「改革開放」に伴って進展している 耕地についての質における格差と量的問題による 食糧問題と環境悪化について論じられている。第 6 章では, 人口動態にかかわる出生率・死亡率・ 平均寿命などの数字を駆使して省別の地域差を軸 に論じられている。この 2 つの章に共通する問題 点として, 耕地問題・環境破壊問題について政府 の統計数字問題の不十分性について屯言及されて いる。第 7 章では, いわゆる 1 人っ子政策から二 十数年が経過した現在, 中国の伝統的家族制度か らの激変と残存・復活をめぐって, 家族の変容・ リプロダクティブ問題・教育問題などの困難な問 題を抱えていることが具体例を交えて論じられて いる。第 12 章では, 人口動態の変化を受けて当 然生じる高齢化問題と対応の具体例について言及 されている。1 人っ子政策・市場経済化・国有企 業の倒産などに起因する土地と単位という社会保 障体制のくずれにたいして, 中国では一定の改革 の方向が出されていることが挙げられているが, 著者は「混沌とした情勢下にある」と結んでいる。 全体としては中国の実状の紹介という性格のこの 本については, 膨大な統計数字などの活用の仕方 は読む者に委㸚られることになろう。

人口問題が他の社会的諸問題之密接に関連して いることは目次を見れば明らかであるが，昨今の 中国研究（だけではないが）の傾向として，きわ めて部分的な「現実」を落下傘降下して調べるよ うな「研究」が多いことを指摘することができる。 そのような動向のあとで, 本書の意義は 3 つある と私は受け止めた。1. 全体的動向をマクロレベ ルでフォローしていること。2. 中国の人口問題 
が中国だけでなく世界的な人口問題であること。 3. 人口問題を他の社会的現実とかかわらせて論 じていること。認識における濃淡の差はあって あ, 中国を論じるには少なくともこの程度の全体 的認識がベースとして要請されるという意味で, 私自身む学ぶことが多く有り難い本であった。そ のような意義を認めた上で, 著者だけにというよ りは社会学から中国研究にかかわる者にたいして 私なりの問いを発して, 若干の方向提示をした い。あっとも基本的なこととして，〈人口問題とは 何か〉ということと〈社会的現実をどう見るか〉 という 2 つが問われる。

そもそも人口問題之は何かが問われるのである が, とりわけ社会学では人口問題をどのように考 えるかを基本的に押さえておくことが大事であ る。社会の存続にとっては生活資料の生産と人間 の生産は不可欠な二大条件である。人口の再生産 が後者に該当することは言うまでもないであろ う。これを「社会的現実」との関連で問うならば, 量としての面では, 主として総人口数, 年齢構成, 地域的編成の変化動向を挙げることができる。質 としての面では, 人口（=人間の生産）の変化動 向が経済的生産力によ゙のように照応しているかし ていないか, 教育程度や文化的特質はどうかとい うことを制度・政策との関連で取り上げる必要が ある。人口問題を取り上げるにあたっての「社会 的現実」についての大枠として上に挙げた変化動 向が本書では措定されているが, 私自身は「人口 問題」が専門ではなく, 著者のような膨大な文 献・資料の蓄積を持っていないので, 私見を全面 的に対置できない。ここではこのような研究の今 後の発展にとって不十分と思われる「社会的現
実」の枠組みについて提起するによよ゙める。最近 の十数年間における中国の「社会的現実」にとっ て大きな意味があるのは, 地域的特質の複雑化と 階層・階級の分化の進展である。前者については 本書では都市之農村, 省, 東部之西部という区分 で分析されている。はたしてそれだけでよいの か。都市屯農村も多様であり，いわゆる都市身分 と農村身分がかなり固定していた 1990 年代中頃 までは都市家族と農村家族という一括した把握で こと足りたかむしれないが，人口・身分の流動が 進んでいる現段階では区分をさらに進める方向が 求められている。具体的に例示するならば, 貧困 農村と富裕農村, 大都市近郊農村と遠隔地農村な

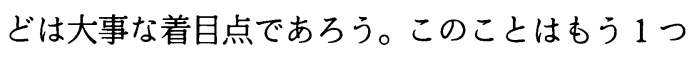
の階層・階級の分化の進展という「社会的現実」 之密接に結びっいている。1990年代後半から 「階層分化」が急速に進展するとともに, 中国の社 会学者による研究が多くなっており, 私の手許に だけであ 10 数冊ある。そのうちの 1 つだけ例示 すると，3つの最上層にはほとんど移動がなく， また 4 つの下層には上昇移動がなくて，6つの中 間層間で移動があるが，上昇移動が限られている という報告がなされている。人口問題研究の発展 にとっては，以上簡単に指摘した「社会的現実」 を視野に入れることが重要になっていると思われ る。最後に蛇足として，これまた著者だけの問題 ではなく留学生に多いのだが, 中国語が漢字であ るためにそのまま使われていること, 例として 「退休」,「街道」の 2 つだけ指摘しておこう。「定 年退職」,「町 (内)」と中国語を知らない者むわか る日本語表現が望ましいことを付け加えて, 書評 らしからぬ書評を結ぶことにする。 